\title{
The Role of Academic Supervision Variables, School Culture, and Work Motivation on Teacher Performance Senior High School
}

\author{
Marzuki*, Murniati, Yusrizal \\ Educational Administration Postgraduate \\ Universitas Syiah Kuala \\ Banda Aceh, Indonesia \\ *marzuki14@mhs.unsyiah.ac.id,murniati@unsyiah.ac.id,yusrizal_fkip@unsyiah.ac.id
}

\begin{abstract}
This study aims to determine the effect of academic supervision variables, work motivation, and school culture on teacher performance. The research method uses a mixed-method approach to sequential explanatory models. The research subjects were 106 teachers and 53 high school students in one district in Aceh. Quantitative data collection through questionnaires is then followed by collecting and analyzing qualitative data through interviews. The results showed that the variables of academic supervision, school culture, and work motivation simultaneously affected teacher performance. whereas partially only the work motivation and school culture variables have a positive effect on teacher performance, while the partial supervision variable does not affect teacher performance.
\end{abstract}

Keywords-academic supervision, work motivation, school culture, teacher performance

\section{INTRODUCTION}

One of the factors that affect teacher performance is coaching by the principal through supervision. According to Mark, "One of the extrinsic factors that significantly contribute to work motivation, achievement, and teacher professionalism is the supervision of the principal."[1]. Teachers' low motivation and achievement that affect the teaching profession is inseparable from the low contribution of school principals in fostering teachers in schools through supervision activities.

As a good supervisor, the principal must have a plan, carry out supervision according to the program, carry out evaluations, and carry out follow-ups. The results of the observations showed that the supervision carried out by the principal was not well planned. This is following the results of previous research "found that $90 \%$ of school principals who carry out supervision are not complete with administrative completeness (planning, implementation, evaluation, and follow-up), and the principal has not carried out their primary duties as supervisor [2]. The results of previous research show that academic supervision has a positive effect on teacher performance [3-5].
Also, considering that schools are the leading formal education implementation unit with various potentials for students who require various educational services, environmental conditions are different. Strong school culture is a force that can unite goals, create motivation and commitment. And the loyalty of all school members and providing the necessary structure and control without relying on formal bureaucracy. A strong school culture will foster and increase motivation and innovation, which impacts improving school performance. This is following the results of previous studies which show that school culture greatly influences teacher performance improvement [6,7].

Apart from school culture, teacher work motivation is also a significant factor in influencing teacher performance to achieve educational goals. Motivation is the driving force for someone to carry out an activity manifested in actual actions [8]. Thus the higher a person's motivation, the higher the performance, and vice versa, the lower the person's motivation, the lower the performance. Previous research has shown that work motivation is very influential on teacher performance [9]. If teachers have high work motivation, they will be motivated and try to improve their abilities in planning, implementing, and evaluating the curriculum applicable in schools to get maximum work results.

Based on the explanation above, in this study, we examined the effect simultaneously and partially on the variables of academic supervision, motivation, and school culture on teacher performance. The results of this study are expected to become a reference and input for policies that lead to improved teacher performance.

\section{METHODS}

This study intends to examine the effect simultaneously and partially between academic supervision, school culture, work motivation on teacher performance. The research was designed as a survey research that was explaining phenomena (explanatory research). The aim, in addition to presenting a 
situation that occurred when the research was carried out. In addition, it is also designed to determine the presence or absence of an influence between two or more variables and to what extent the effect is.

This study used a mix-methods approach with a sequential explanatory model, namely analyzing quantitative data through a questionnaire, then collecting and analyzing qualitative data through interviews [10]. The facts that occur and the results of the study will illustrate the influence of academic supervision, school culture, and work motivation on public high school teachers' performance in a district in Aceh (Table 1).

TABLE I. RESEARCH VARIABLES

\begin{tabular}{|c|c|c|c|}
\hline No. & Variable & Dimensions & Information \\
\hline \multirow{3}{*}{1} & \multirow{3}{*}{$\begin{array}{l}\text { Academic } \\
\text { Supervision }\end{array}$} & Curriculum Development & \multirow{3}{*}{$\begin{array}{l}\text { Independent } \\
\text { Variable }\end{array}$} \\
\hline & & Observation & \\
\hline & & $\begin{array}{ll}\text { Teacher } & \text { Professional } \\
\text { Development } & \end{array}$ & \\
\hline \multirow{4}{*}{2} & \multirow{4}{*}{$\begin{array}{l}\text { School } \\
\text { Culture }\end{array}$} & Culture of Affication & \multirow{4}{*}{$\begin{array}{l}\text { Independent } \\
\text { Variable }\end{array}$} \\
\hline & & Culture of Belief & \\
\hline & & Culture of Optimism & \\
\hline & & Culture of Control & \\
\hline \multirow{2}{*}{3} & \multirow{2}{*}{$\begin{array}{l}\text { Work } \\
\text { motivation }\end{array}$} & Internal motivation & \multirow{2}{*}{$\begin{array}{l}\text { Independent } \\
\text { Variable }\end{array}$} \\
\hline & & External motivation & \\
\hline \multirow{6}{*}{4} & \multirow{6}{*}{$\begin{array}{l}\text { Teacher } \\
\text { Performance }\end{array}$} & Learning Planning & \multirow{6}{*}{$\begin{array}{l}\text { Dependent } \\
\text { Variable }\end{array}$} \\
\hline & & Implementation of Learning & \\
\hline & & $\begin{array}{lll}\text { Carry out Interpersonal } \\
\text { Relations }\end{array}$ & \\
\hline & & $\begin{array}{l}\text { Carry out Assessment Process } \\
\text { and Learning Outcomes }\end{array}$ & \\
\hline & & $\begin{array}{l}\text { Implementing the Enrichment } \\
\text { Program }\end{array}$ & \\
\hline & & Implement Remdial Program & \\
\hline
\end{tabular}

Data collection techniques were carried out through questionnaires and interviews. Questionnaires were given to 53 teacher and student respondents in mathematics and science at the high school level in a district of Aceh. The four-choice Likert scale questionnaire is always (Score 4), often (Score 3), Rarely (Score 2), never. Meanwhile, interviews were conducted to explore additional data needed to support the results of the data analysis.

Data analysis techniques Multiple linear regression analysis methods using SPSS Version 25. This analyst aims to see whether there is a partial and simultaneous influence on the variables of academic supervision, school culture, and work motivation on teacher performance.

\section{RESULTS AND DISCUSSION}

\section{A. Research Result}

Before the statistical test was carried out, the questionnaire data for academic supervision, work motivation, school culture, and teacher performance were first tested for normality. The regression model is normally distributed if the plotting data describes the accurate data follows a diagonal line [11]. The normality test results show that the plotting data follows a diagonal line, as shown in Figure 1 It can be concluded that the data is normally distributed.

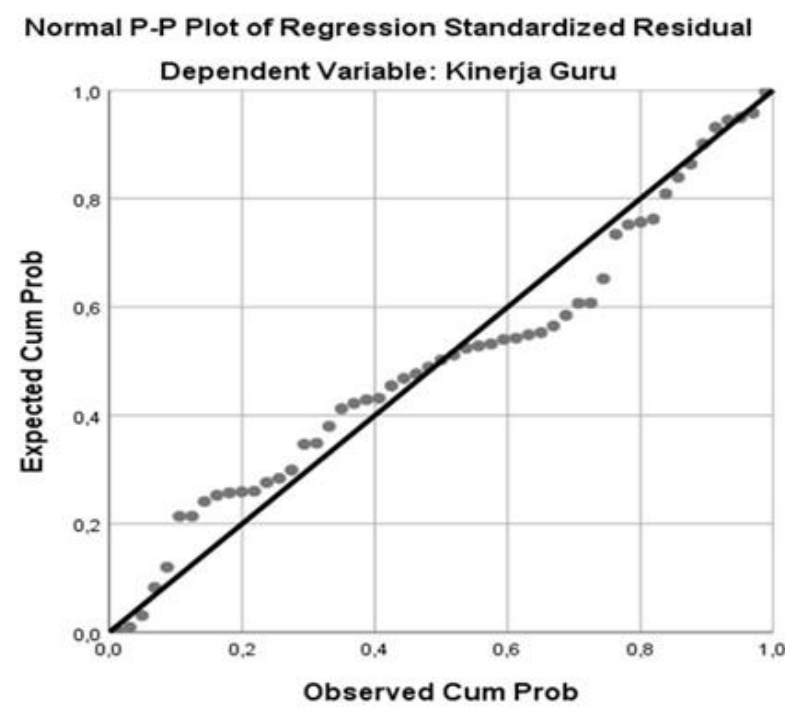

Fig. 1. Output normality regression test with SPSS

Furthermore, multiple regression tests were carried out to determine the simultaneous influence of the variables of academic supervision, school culture, and work motivation on teacher performance. The test results as shown in table 2 show that academic supervision, school culture, and work motivation simultaneously affect teacher performance (Sig. $=0.000$ $<0.05)$.

TABLE II. MultiPle REgRESSION TEST RESUlts

\begin{tabular}{|c|c|c|c|c|c|c|}
\hline \multicolumn{2}{|c|}{ ANOVAa } \\
\hline \multirow{2}{*}{1} & Model & $\begin{array}{c}\text { Sum of } \\
\text { Squares }\end{array}$ & $\boldsymbol{d} \boldsymbol{f}$ & Mean Square & $\boldsymbol{F}$ & \multirow{2}{*}{ Sig. } \\
\cline { 2 - 6 } & Regression & 832,620 & 3 & 277,540 & 57,721 & $0.000 \mathrm{~b}$ \\
\cline { 2 - 5 } & Residual & 235,606 & 49 & 4,808 & & \\
\cline { 2 - 5 } & Total & 1068,226 & 52 & & & \\
\hline
\end{tabular}

To see how much influence, it simultaneously can be seen in table 3. The $\mathrm{R}$ Square value of $77.90 \%$ indicates the magnitude of the impact of academic supervision variables, school culture, and work motivation simultaneously on teacher performance variables. Meanwhile, $\mathrm{R}$ of 0.883 shows a strong correlation between academic supervision, school culture, and work motivation simultaneously on teacher performance variables $(0.71 \leq \mathrm{R} \geq 90$, strong category).

TABLE III. Multiple LinEAR RESUlts SEEING SimultaneOUS EFFECTS

\begin{tabular}{|c|c|c|c|c|c|}
\hline \multicolumn{7}{|c|}{ Model Summary $^{\mathbf{b}}$} \\
\hline Model & $\boldsymbol{R}$ & $\boldsymbol{R}$ Square & $\begin{array}{c}\text { Adjusted } \boldsymbol{R} \\
\text { Square }\end{array}$ & $\begin{array}{c}\text { Std. Error of } \\
\text { the Estimate }\end{array}$ & $\begin{array}{c}\text { Durbin- } \\
\text { Watson }\end{array}$ \\
\hline 1 & 0.883 & 0.779 & 0.766 & 2.192 & 2,318 \\
\hline
\end{tabular}


Table 4 shows the linear regression test results to see the partial effect of academic supervision, work motivation, and school culture on teacher performance. The results of data analysis showed that school culture variables (sig. $=0.003$ $<0.05$ ) and work motivation (sig. $=0.001<0.05$ ) partially affect teacher performance. The two variables of school culture influence or contribute effectively to teacher performance by $31.42 \%$ and $34.9 \%$ for the motivation variable. While the academic supervision variable partially does not have a significant effect on teacher performance $(\mathrm{sig}=0.090<0.05)$.

TABLE IV. Multiple Linear Results SeEING Partial EfFects

\begin{tabular}{|c|c|c|c|c|c|c|}
\hline \multicolumn{8}{|c|}{ Coefficients $^{\mathbf{a}}$} \\
\hline \multirow{3}{*}{1} & Model & $\boldsymbol{B}$ & Std. Error & Beta & $\boldsymbol{t}$ & Sig. \\
\cline { 2 - 7 } & (Constant) & 8,834 & 6,302 & & 1,402 & 0.167 \\
\cline { 2 - 7 } & Academic Supervision & 0.164 & 0.095 & 0.165 & 1,731 & 0.090 \\
\cline { 2 - 7 } & School Culture & 0.383 & 0.122 & 0.379 & 3,138 & 0.003 \\
\cline { 2 - 7 } & Work motivation & 0.362 & 0.107 & 0.416 & 3,386 & 0.001 \\
\hline \multicolumn{8}{|c|}{ a. Dependent Variable: Teacher Performance } \\
\hline
\end{tabular}

\section{B. Discussion}

Academic supervision is something that must be considered in improving teacher performance. But in fact, academic supervision does not partially affect teacher performance. From the results of observations and interviews with school principals, they admit that "the supervision process has not gone as expected and is not programmed." The same thing was also recognized by teachers who said that "the supervision process was not carried out in a programmed manner." It can be concluded that the implementation of academic supervision has not been optimal for schools, so it does not have a significant impact on teacher performance. This is in accordance with Harun's opinion, which states that "in order to improve teacher performance, academic supervision needs to be optimized [12].

Work motivation is also essential in improving teacher performance. Positive motivation will motivate teachers to do positive things for themselves and others, which teachers can then apply at work and in their daily lives. This is proven both simultaneously and partially work motivation variables both internally and externally positively affect teacher performance. The results of previous research indicate a positive relationship between self-work motivation (internal) and external motivation (external) on teacher performance [2,6,7].

In addition, school culture is very important for the development of teacher performance because school culture is the key to these schools' success in carrying out the learning process. The results showed that both simultaneously and partially had a positive effect on teacher performance. The study results are by the results of previous studies that show that school culture has a positive impact on teacher performance [9]. The work culture of a teacher in the learning process dramatically determines the achievement of educational goals. The teacher's work culture can be seen from the extent of their sense of responsibility in carrying out their mandate, the profession they carry, and their sense of moral responsibility. All of this will be seen in their compliance and loyalty in carrying out their primary duties and functions in the learning process. This attitude will be accompanied by a sense of responsibility to make and prepare the administration of the teaching and learning process, implement the teaching and learning process, and carry out evaluations in teaching and learning activities.

\section{CONCLUSION}

Based on the research results, it can be concluded that the academic supervision variable simultaneously has a positive effect on teacher performance. In contrast, partially, the theoretical supervision variable does not affect this performance. Supervision has not been carried out programmatically and adequately to have no real impact on improving teacher performance. Meanwhile, the variables of work motivation and school culture, both simultaneously and partially, positively affect teacher performance.

The research results are expected; (1) to schools so that supervision activities are carried out in a programmed manner so that they can provide tangible benefits to improving teacher performance; (2) Principals need to work together with school members in creating a good work culture to support teacher performance, and (3) schools need to preserve a work environment that reminds one another, helps each other among school members to increase good work motivation to improve teacher performance.

\section{REFERENCES}

[1] J.R. Marks, Handbook of educational supervision: A guide for the practitioner Boston: Allyn \& Bacon Inc., 1985.

[2] E. Sujatiningtyas, "Supervisi Kepala Sekolah, Budaya Organisasi, Dan Motivasi Kerja: Pengaruhnya Terhadap Kinerja Guru,” Jurnal Penelitian dan Pendidikan IPS, vol. 12, pp. 8-13, 2018.

[3] R. Dos Santos, R. Rusdarti, and S.E. Mulyono, "the effect of academic supervision and principal's leadership on teacher performance through work motivation in SD Negeri Taasifeto Barat Belu District, East Nusa Tenggara," Educational Management, vol. 9, pp. 23-33, 2020.

[4] R.A. Rifai, and M. Harlanu, The Effect of Academic Supervision and Teacher Participation in Subject Teacher's Meeting on Improving Teacher Performance of Islamic Junior High School. In International Conference on Science and Education and Technology (ISET 2019) (pp. 143-146). Atlantis Press, 2020.

[5] R. Japemar, and A. Fauzan, "The Effect of Academic Supervision, School Leadership, Organizational Culture, and Achievemen Motivation on Teachers' Performance at Junior High Schools," Advances in Social Science, Education and Humanities Research, vol 504, pp. 177-180, 2020.

[6] M.S. Haq and B.N. A'yun, The Influence of Teacher Performance and School Culture on School Quality. In International Joint Conference on Arts and Humanities (IJCAH 2020) (pp. 87-91). Atlantis Press, 2020

[7] T.B.G. Egziabher and S. Edwards, "School Culture And Teacher Job Performance: A Comparative Analysis of The Perception of Teaching Staff In Private And Public Basic Schools in Ga South Municipality Africa's potential Ecol,” Intensif. Agric. Vol. 53, pp. 1689-1699, 2013. 
[8] M.N. Mustafa and N. Othman, "The effect of work motivation on teacher's work performance in pekanbaru senior high schools, Riau Province, Indonesia," Sosiohumanika, vol. 3, pp. 259-272, 2010.

[9] S. Andriani, N. Kesumawati, and M. Kristiawan, "The influence of the transformational leadership and work motivation on teachers performance," International Journal of Scientific \& Technology Research, vol. 7, pp. 19-29, 2018.
[10] J.W. Creswell, Research design: pendekatan kualitatif, kuantitatif, dan mixed Yogjakarta: PT Pustaka Pelajar, 2010.

[11] I. Ghozali, Aplikasi Analisis Multivariate dengan Program IMB SPSS 19, Semarang: Badan Penerbit Undip Semarang, 2011.

[12] H. Harun, "Optimalisasi Pelaksanaan Supervisi Akademik Dalam Upaya Meningkatkan Kinerja Guru Sd Negeri 49 Cakranegar,”a GaneÇ Swara vol. 10, pp. 149-153, 2016. 